\title{
$\mathrm{Ce}$ 가 첨가된 $\mathrm{Pt} / \gamma-\mathrm{Al}_{2} \mathrm{O}_{3}$ 촉매의 선택적 $\mathrm{CO}$ 산화반응 특성
}

\author{
김기혁 · 구기영 · 정운호 · 윤왕래 ${ }^{\dagger}$ \\ 한국에너지기술연구원 수소연료전지 연구단
}

\section{Preferential CO Oxidation over Ce-Promoted $\mathrm{Pt} / \gamma-\mathrm{Al}_{2} \mathrm{O}_{3}$ Catalyst}

\author{
KIHYEOK KIM, KEEYOUNG KOO, UNHO JUNG, WANGLAI YOON ${ }^{\dagger}$ \\ Hydrogen and Fuel Cell Department, Korea Institute of Energy Research, 152 Gajeong-ro, \\ Yuseong-gu, Daejeon 305-343, Korea
}

\begin{abstract}
The effect of Ce promotion over $1 \mathrm{wt} \% \mathrm{Pt} / \mathrm{\gamma}-\mathrm{Al}_{2} \mathrm{O}_{3}$ catalysts on the $\mathrm{CO}$ conversion and $\mathrm{CO}_{2}$ selectivity was investigated in preferential $\mathrm{CO}$ oxidation (PrOx) to reduce the $\mathrm{CO}$ concentration less than $10 \mathrm{ppm}$ in excess $\mathrm{H}_{2}$ stream for polymer electrolyte membrane fuel cell (PEMFC). Ce-promoted $1 \mathrm{wt} \% \mathrm{Pt} / \gamma-\mathrm{Al}_{2} \mathrm{O}_{3}$ catalysts were prepared by incipient wetness impregnation method and the loading amount of Pt was fixed at $1 \mathrm{wt} \%$. The content of Ce promoter which has excellent oxygen storage and transfer capability due to the redox property was adjusted from 0 to $1.5 \mathrm{wt} \%$. Ce-promoted $1 \mathrm{wt} \% \mathrm{Pt} / \mathrm{\gamma}-\mathrm{Al}_{2} \mathrm{O}_{3}$ catalysts exhibit high $\mathrm{CO}$ conversion and $\mathrm{CO}_{2}$ selectivity at low temperatures below $150^{\circ} \mathrm{C}$ due to the improvement of reducibility of surface PtOx species compared with the $1 \mathrm{wt} \% \mathrm{Pt} / \mathrm{\gamma}-\mathrm{Al}_{2} \mathrm{O}_{3}$ catalyst without $\mathrm{Ce}$ addition. When Ce content was more than $1 \mathrm{wt} \%$, the catalytic activity was decreased at over $160^{\circ} \mathrm{C}$ in PrOx because of competitive $\mathrm{H}_{2}$ oxidation. As a result, $0.5 \mathrm{wt} \% \mathrm{Ce}$ is optimal content not only to achieve high catalytic activity and good stability at low temperatures below $150^{\circ} \mathrm{C}$ in the presence of $\mathrm{CO}_{2}$ and $\mathrm{H}_{2} \mathrm{O}$ but also to minimize the $\mathrm{H}_{2}$ oxidation at high temperatures.
\end{abstract}

Key words : Preferential $\mathrm{CO}$ Oxidation(선택적 $\mathrm{CO}$ 산화), $\mathrm{Pt}-\mathrm{Ce} / \mathrm{Al}_{2} \mathrm{O}_{3}$ catalyst, Ceria

\section{1. 서 론}

선택적 $\mathrm{CO}$ 산화반응은 개질 가스 내 불순물인 $\mathrm{CO}$ 를 제거하여 고농도 수소를 제조하는 경제적이고 효과적인 $\mathrm{CO}$ 정제(cleaning) 공정으로서 ${ }^{1)}$ 고분자 전 해질 연료전지(PEMFC) 전극 촉매인 $\mathrm{Pt}$ 의 $\mathrm{CO}$ 피독 으로 인한 전지성능의 저하를 막기 위해 반응원료로 사용되는 수소 가스 내의 $\mathrm{CO}$ 농도를 $10 \mathrm{ppm}$ 이하로 제거하기 위한 단위 반응공정이다.

\footnotetext{
${ }^{\dagger}$ Corresponding author : wlyoon@kier.re.kr [ 접수일 : 2012.11.30 수정일 : 2012.12.28 게재확정일 : 2012.12.31 ] Copyright (c) 2012 KHNES
}

개질가스 내에서 선택적 $\mathrm{CO}$ 산화반응은 $\mathrm{CO}$ 산화 반응과 $\mathrm{H}_{2}$ 산화반응이 경쟁적으로 일어나는 발열 반 응으로 반응 온도가 증가함에 따라 상대적으로 빈도 인자(frequency factor)가 큰 수소 산화 반응이 우세 해져 $\mathrm{CO}$ 선택도가 떨어지기 때문에 반응온도 조절 이 중요하다 ${ }^{2)}$.

$$
\mathrm{CO}+\frac{1}{2} \mathrm{O}_{2} \rightarrow \mathrm{CO}_{2} \quad \text { (desired reaction) }
$$

$$
\mathrm{H}_{2}+\frac{1}{2} \mathrm{O}_{2} \rightarrow \mathrm{H}_{2} \mathrm{O} \text { (undesired reaction) }
$$

효과적인 $\mathrm{CO}$ 제거를 위해서 선택적 $\mathrm{CO}$ 산화반응 
촉매는 넓은 온도영역 $\left(100-200^{\circ} \mathrm{C}\right)$ 에서 높은 $\mathrm{CO}$ 전환 율과 선택도를 가지며 실제 개질 가스 내에 존재하 는 불순물 $\left(\mathrm{H}_{2} \mathrm{O}, \mathrm{CO}_{2}\right)$ 에 대한 높은 피독 저항성이 요 구된달. 일반적으로 선택적 $\mathrm{CO}$ 산화 반응 촉매에는 $\mathrm{Cu}-\mathrm{CeO}_{2}$ 등의 금속산화물 촉매와 $\mathrm{Pt}, \mathrm{Ru}, \mathrm{Au}$ 와 같은 귀금속 계열 촉매가 있다. 금속산화물 촉매는 귀금속 촉매에 비해 경제적이지만 작동 온도영역이 좁고 낮 은 산화활성과 불순물 $\left(\mathrm{H}_{2} \mathrm{O}, \mathrm{CO}_{2}\right)$ 에 의해 쉽게 비활 성화 되는 문제점이 있다. 반면에 우수한 $\mathrm{CO}$ 산화반 응 활성과 안정성을 갖는 귀금속계 촉매의 경우, 고가 로 인한 경제적인 제한점이 있다. 이를 해결하고자 소 량의 귀금속을 고분산 담지하거나 조촉매를 첨가하여 촉매 활성을 향상시키는 연구가 진행되고 있다무)

본 연구에서는 다양한 귀금속 촉매 중에 $\mathrm{Pt}$ 를 기 본 촉매 활성성분으로 선정하였다. 일반적으로 $\mathrm{Ru} / \mathrm{Al}_{2} \mathrm{O}_{3}$ 촉매는 온도가 상승할수록 메탄화 반응이 발생하여 수소손실이 높은 문제점이 있다 ${ }^{7)} . \mathrm{SiO}_{2}, \mathrm{Al}_{2} \mathrm{O}_{3}, \mathrm{MgO}$ 와 같은 여러 담체에 $\mathrm{Au}$ 가 담지된 촉매의 경우, 저온 $\left(<150^{\circ} \mathrm{C}\right)$ 에서 매우 우수한 촉매활성을 보였으나 촉 매활성이 안정적이지 못하고 제조 과정이나 전구체 에 따라 촉매 활성 차이가 크기 때문에 재현성 있는 연구결과를 얻기가 힘들다고 Schubert 등이 보고한 바 있달. 그에 반해 $\mathrm{Pt} / \mathrm{Al}_{2} \mathrm{O}_{3}$ 촉매는 $170-230^{\circ} \mathrm{C}$ 온 도영역에서의 우수한 촉매활성과 안전성을 보이고 부반응인 메탄화반응이 발생하지 않는 특징을 갖고 있다. 일반적으로, 작동온도범위가 $80-120^{\circ} \mathrm{C}$ 로 낮은 고분자 전해질 연료전지 적용을 위해서는 저온에서 우수한 선택적 CO 산화 반응 활성을 갖는 촉매 개발 이 요구된다. $\mathrm{Pt} / \mathrm{Al}_{2} \mathrm{O}_{3}$ 촉매는 $160^{\circ} \mathrm{C}$ 이하의 저온 반 응에서 낮은 촉매활성을 보이는 제한점이 있으며, 이 를 해결하기 위해 $\mathrm{Ce}^{9)}, \mathrm{K}^{10)}, \mathrm{Fe}^{11)}, \mathrm{Ni}^{12)}, \mathrm{Co}^{13)}$ 등의 비 귀금속 물질을 조촉매로 첨가하여 저온활성을 향상 시키는 선행 연구들이 보고된 바 있다. 뿐만 아니라, 단일성분의 $\mathrm{Pt}$ 촉매와 $\mathrm{Ru}$ 촉매의 제한된 온도 영역을 넓히기 위해서 Pt-Ru 합금촉매에 대한 연구도 수행 되었다 ${ }^{14)}$. 특히, $\mathrm{Ce}$ 를 조촉매로 첨가한 경우, $\mathrm{Ce}$ 의 우수한 산화환원 및 산소저장 특성으로 인해 $\mathrm{CO}$ 산
화 활성과 선택도의 향상을 기대할 수 있다.

본 연구에서는 $\mathrm{Pt} / \mathrm{\gamma}-\mathrm{Al}_{2} \mathrm{O}_{3}$ 촉매에 조촉매로써 $\mathrm{Ce}$ 를 첨가하여 저온에서 선택적 $\mathrm{CO}$ 산화반응의 촉매활성 과 $\mathrm{CO}_{2}$ 선택도를 향상시키고 첨가되는 $\mathrm{Ce}$ 의 함량을 최적화하고자 하였다. 또한, 실제 개질공정에서 선택 적 $\mathrm{CO}$ 산화반응의 중요한 반응 변수인 불순물 $\left(\mathrm{H}_{2} \mathrm{O}\right.$, $\mathrm{CO}_{2}$ )에 대한 영향을 살펴보았다.

\section{2. 실 험}

\section{1 촉매 제조}

Chloroplatinic acid hexahydrate $\left(\mathrm{H}_{2} \mathrm{PtCl}_{6} \cdot 6 \mathrm{H}_{2} \mathrm{O}\right.$, Aldrich) 와 Cerium(III) nitrate hexahydrate $\left(\mathrm{Ce}\left(\mathrm{NO}_{3}\right)_{3} \cdot 6 \mathrm{H}_{2} \mathrm{O}\right.$, Aldrich)을 $\mathrm{Pt}$ 와 $\mathrm{Ce}$ 전구체로 사용하였고, $\gamma-\mathrm{Al}_{2} \mathrm{O}_{3}$ (SASOL)담체에 $\mathrm{Pt}$ 와 $\mathrm{Ce}$ 전구체를 녹인 혼합 용액을 함침법(incipient wetness impregnation method)으로 담지하였다. Pt 함량은 $1 \mathrm{wt} \%$ 로 고정하였고 조촉매인 $\mathrm{Ce}$ 함량은 0-1.5wt\%로 조절하였다. 제조된 촉매는 공기 분위기 하에서 $400^{\circ} \mathrm{C}, 4$ 시간 소성하였다.

\section{2 특성 분석}

BET 분석(Belsorp max, BEL Japan, INC.)을 통하 여 제조 촉매의 비표면적을 측정을 하였다. 샘플 $0.4 \mathrm{~g}$ 을 $200^{\circ} \mathrm{C}$ 진공상태에서 3 시간정도 전처리하여 $-197^{\circ} \mathrm{C}$ 에서 질소의 물리적 흡착량을 통해 샘플의 비표면적 을 계산하였다. Pt 분산도와 Pt 입자크기를 계산하기 위하여 CO 화학 흡착(BEL METAL-3, BEL JAPAN $\mathrm{INC}$.)을 수행하였다. 샘플 $0.05 \mathrm{~g}$ 을 U자형 샘플 튜브 에 넣고 분석 장치에 장착한 뒤 $\mathrm{He}$ 분위기 하에서 $400^{\circ} \mathrm{C}$ 까지 승온시킨 후 $\mathrm{H}_{2}$ 가스로 전처리하였으며, $50^{\circ} \mathrm{C}$ 까지 냉각하여 $10 \% \mathrm{CO} / \mathrm{He}$ 가스를 펄스 방법으 로 주입하였다. Pt 분산도는 Pt:CO = 1:1로 화학 흡 착하는 것으로 가정하여 계산하였다. 제조된 촉매의 환원특성을 알아보기 위하여 $\mathrm{H}_{2}$-TPR분석(BEL CAT $\mathrm{B}, \mathrm{BEL}$ Japan, Inc.)을 수행하였다. 샘플 $0.1 \mathrm{~g}$ 을 U자 형 샘플튜브에 넣고 분석 장치에 장착한 후 $10 \%$ 
Table 1 Characteristics of $1 \mathrm{wt} \% \mathrm{Pt}-\mathrm{Ce} / \mathrm{\gamma}-\mathrm{Al}_{2} \mathrm{O}_{3}$ catalysts with various $\mathrm{Ce}$ Contents

\begin{tabular}{c|c|c|c}
\hline \hline $\begin{array}{c}\mathrm{Ce} \\
\text { 함량 }(\%)\end{array}$ & $\begin{array}{c}\text { BET } \\
\left(\mathrm{m}^{2} / \mathrm{g}\right)\end{array}$ & $\begin{array}{c}\text { Metal } \\
\text { dispersion }(\%)\end{array}$ & $\begin{array}{c}\text { Particle } \\
\text { size }(\mathrm{nm})\end{array}$ \\
\hline 0.0 & 150.1 & 74.5 & 1.50 \\
\hline 0.5 & 148.8 & 72.5 & 1.56 \\
\hline 1.0 & 148.7 & 71.8 & 1.58 \\
\hline 1.5 & 146.0 & 70.1 & 1.62 \\
\hline
\end{tabular}

$\mathrm{H}_{2} / \mathrm{Ar}$ 가스를 흘려주면서 상온에서 $500^{\circ} \mathrm{C}$ 까지 $5^{\circ} \mathrm{C}$ $/ \mathrm{min}$ 의 속도로 온도를 상승시키며 수소 소모량을 $\mathrm{TCD}$ 로 측정하여 분석을 수행하였다.

\section{3 실험 방법}

반응기는 상압 고정층 미분 반응기를 사용하였고, 60-100mesh 크기의 촉매를 $\mathrm{MgAl}_{2} \mathrm{O}_{4}$ diluent와 혼합 하여 반응기에 충진 후 반응을 수행하였다. 반응 전 촉매를 $400^{\circ} \mathrm{C}$ 에서 3 시간 동안 $10 \% \mathrm{H}_{2} / \mathrm{N}_{2}$ 분위기 하 에서 환원처리 하였으며 촉매층 중간에 열전대를 설 치하여 반응온도를 제어하였다. 반응가스는 $59 \% \mathrm{H}_{2}$, $0.61 \% \mathrm{CO}, 0.61-1.22 \% \mathrm{O}_{2}, \mathrm{~N}_{2}$ balance로 공급하였고, $100-200^{\circ} \mathrm{C}$ 반응온도와 공간속도 $(\mathrm{F} / \mathrm{W}) 60,000 \mathrm{ml} / \mathrm{g}_{\text {cat }} \mathrm{h}$ 에서 수행하였다. 또한 반응실험에서 $\mathrm{CO}_{2}$ 와 $\mathrm{H}_{2} \mathrm{O}$ 의 영향을 살펴보기 위하여 $1.22 \% \mathrm{O}_{2}, 0.61 \% \mathrm{CO}, 59 \%$ $\mathrm{H}_{2}, \mathrm{~N}_{2}$ balance를 고정한 뒤 $16 \% \mathrm{CO}_{2}$ 와 $19 \% \mathrm{H}_{2} \mathrm{O}$ 를 첨가하여 실험하였다. 반응 후 가스는 트랩을 거쳐 수분 제거 후 micro GC (Agilent 3000)을 통해 성분 을 분석하였다. $\mathrm{CO}$ 선택적 산화반응에 있어 $\mathrm{CO}$ 전 환율, $\mathrm{O}_{2}$ 전환율, $\mathrm{CO}_{2}$ 선택도는 다음 식들을 이용하 여 계산하였다.

$$
\begin{aligned}
& \text { CO Conversion }(\%)=\frac{[C O]_{I N}-[C O]_{\text {OUT }}}{[C O]_{I N}} \times 100 \\
& O_{2} \operatorname{Conversion}(\%)=\frac{\left[O_{2}\right]_{I N}-\left[O_{2}\right]_{O U T}}{\left[O_{2}\right]_{I N}} \times 100
\end{aligned}
$$

$$
\mathrm{CO}_{2} \text { Selectivity }(\%)=\frac{0.5 \times\left\{[\mathrm{CO}]_{I N}-[\mathrm{CO}]_{\text {OUT }}-\left[\mathrm{CH}_{4}\right]_{\text {OUTT }}\right\}}{\left[\mathrm{O}_{2}\right]_{\mathrm{IN}}-\left[\mathrm{O}_{2}\right]_{\text {OUT }}} \times 100
$$

\section{3. 실험 결과 및 고찰}

\section{1 촉매 특성분석}

$\mathrm{Ce}$ 를 조촉매로 첨가한 $1 \mathrm{wt} \% \mathrm{Pt}-\mathrm{Ce} / \gamma-\mathrm{Al}_{2} \mathrm{O}_{3}$ 촉매 에서 $\mathrm{Ce}$ 함량별 제조 촉매의 비표면적, $\mathrm{Pt}$ 분산도와 입자크기의 특성분석 결과를 Table 1에 정리하였다. $\mathrm{Ce}$ 함량이 증가할수록 촉매의 비표면적과 $\mathrm{Pt}$ 분산도 는 약간 감소하였고 이에 따른 Pt 입자크기가 증가하 였다.

Fig. 1는 제조 촉매의 환원피크를 나타낸 것으로 $\mathrm{Ce}$ 함량에 따른 환원특성의 차이를 살펴보았다. 모 든 제조 촉매는 $180^{\circ} \mathrm{C}$ 와 $350^{\circ} \mathrm{C}$ 사이에서 유사한 환 원피크가 나타났으며 $180^{\circ} \mathrm{C}$ 부근의 환원피크는 surface $\mathrm{PtOx}$ species 환원에 기인한 것이며, $330^{\circ} \mathrm{C}$ 부근에 나타나는 환원 피크는 PtOx species to support interaction에 기인한 것이다 ${ }^{15)}$. 특히, $\mathrm{Ce}$ 를 첨가한 경우 $330^{\circ} \mathrm{C}$ 부근의 환원피크는 고온으로 이동하였는데 이 는 bulk $\mathrm{CeO}_{2}$ 의 환원에 기인한 것으로 설명할 수 있 다 ${ }^{16}$. 또한, $\mathrm{Ce}$ 함량이 증가함에 따라 흡착되는 수소 의 양도 증가하였다. $\mathrm{Ce}$ 함량이 증가함에 따라 $\mathrm{Pt}$ 분 산도는 약간 감소하였으나 오히려 촉매의 환원성은 증가하였는데 이는 $\mathrm{Ce}$ 의 산화환원 특성(redox property) 에 기인한 것이다 ${ }^{9}$. 이를 통해 $\mathrm{Ce}$ 첨가는 촉매의 비

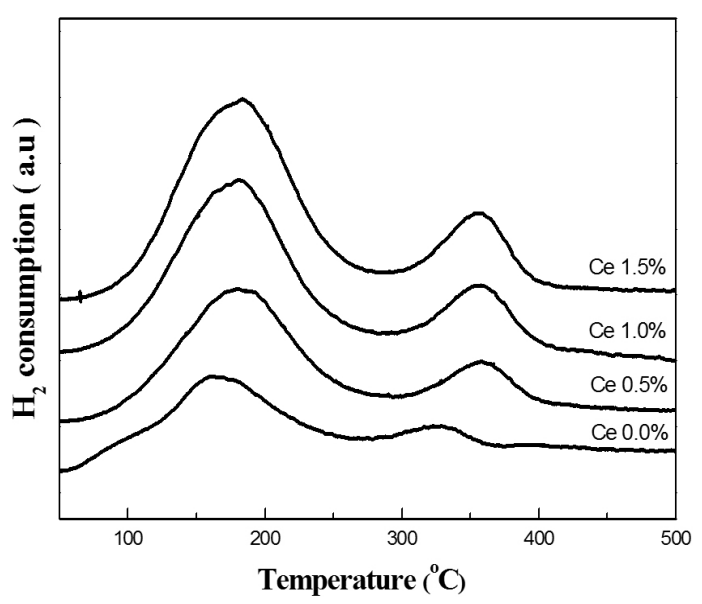

Fig. $1 \mathrm{H}_{2}$-TPR patterns of $1 \mathrm{wt} \% \mathrm{Pt}-\mathrm{Ce} / \gamma-\mathrm{Al}_{2} \mathrm{O}_{3}$ catalysts with various $\mathrm{Ce}$ contents 
표면적과 Pt 분산도에 대한 영향보다는 환원 특성 향 상과 밀접한 관련이 있으며 이는 저온에서 촉매활성 증가에 영향을 미칠 것으로 예상된다.

\section{2 선택적 $\mathrm{CO}$ 산화반응}

Fig. 2는 선택적 $\mathrm{CO}$ 산화반응에서 $\mathrm{Ce}$ 함량에 따른 $1 \mathrm{wt} \% \mathrm{Pt}-\mathrm{Ce} / \mathrm{\gamma}-\mathrm{Al}_{2} \mathrm{O}_{3}$ 촉매의 $\mathrm{CO}$ 전환율, $\mathrm{O}_{2}$ 전환율, $\mathrm{CO}_{2}$ 선택도를 살펴본 결과이다. $\mathrm{Ce}$ 를 첨가하지 않은 $1 \mathrm{wt} \% \mathrm{Pt} / \mathrm{\gamma}-\mathrm{Al}_{2} \mathrm{O}_{3}$ 촉매는 $140^{\circ} \mathrm{C}$ 이하의 저온 반응에 서 $\mathrm{CO}$ 전환율이 $45 \%$ 로 매우 낮은 $\mathrm{CO}$ 산화 반응특 성을 보인 반면, $\mathrm{Ce}$ 를 첨가한 $1 \mathrm{wt} \% \mathrm{Pt}-\mathrm{Ce} / \gamma-\mathrm{Al}_{2} \mathrm{O}_{3}$ 촉 매는 모두 $\mathrm{CO}$ 전환율이 $100 \%$ 로 크게 증가하였다. $\mathrm{Ce}$ 함량별 제조촉매의 선택적 $\mathrm{CO}$ 산화 반응 결과로 부터 $\mathrm{Ce}$ 함량이 증가할수록 $\mathrm{Pt}$ 분산도는 감소하였으 나, 오히려 저온에서의 촉매 활성이 향상됨을 확인하 였다. 이는 앞서 언급하였듯이 $\mathrm{Ce}$ 의 산화환원 특성 에 의한 저온 환원성 향상으로 저온에서 $\mathrm{CO}$ 산화반 응성과 선택성이 증가한 것이다.

$\mathrm{Ce}$ 를 첨가하지 않은 촉매는 $180^{\circ} \mathrm{C}$ 이상에서 $\mathrm{CO}$ 전환율이 감소하였는데, 이는 고온에서 경쟁적으로 일어나는 $\mathrm{H}_{2}$ 산화반응에 기인한 것으로 $\mathrm{CO}$ 보다 빈 도인자가 상대적으로 큰 $\mathrm{H}_{2}$ 의 산화반응이 온도가 상 승할수록 반응이 더욱 우세해지기 때문이다. 반면에, $\mathrm{Ce}$ 가 $1 \mathrm{wt} \%$ 이상 첨가된 촉매는 $160^{\circ} \mathrm{C}$ 부터 서서히 $\mathrm{CO}$ 전환율 감소가 나타났으며 $\mathrm{Ce}$ 를 첨가하지 않은 $1 \mathrm{wt} \% \mathrm{Pt} / \gamma-\mathrm{Al}_{2} \mathrm{O}_{3}$ 촉매보다 $\mathrm{H}_{2}$ 산화반응이 낮은 온도 에서 시작됨을 확인하였다. $\mathrm{O}_{2}$ 전환율은 $140^{\circ} \mathrm{C}$ 이하 의 온도영역에서는 $\mathrm{CO}$ 전환율과 비슷한 경향을 보 였으나, $160^{\circ} \mathrm{C}$ 이상에서는 모두 $100 \%$ 의 $\mathrm{O}_{2}$ 전환율 을 보였다. 이러한 $\mathrm{CO}$ 전환율과 $\mathrm{O}_{2}$ 전환율간의 차이 는 앞서 설명한 바와 같이 $160^{\circ} \mathrm{C}$ 이상에서의 부반응 인 $\mathrm{H}_{2}$ 산화반응에 의한 $\mathrm{O}_{2}$ 소모에 기인한 것이다. 또 한 $\mathrm{CO}_{2}$ 선택도 역시 $\mathrm{Ce}$ 함량이 증가할수록 $160^{\circ} \mathrm{C}$ 이 상에서 감소하였다. 이러한 결과는 $\mathrm{Liu}^{17}{ }^{17)}$ 의 선행연 구와 일치한 결과로 산화환원 특성이 우수한 $\mathrm{Ce}$ 를 조촉매로 첨가한 경우, $\mathrm{H}_{2}$ 산화 반응을 더욱 촉진시 켜 $\mathrm{CO}$ 산화반응에 대한 선택도가 감소하게 된다.
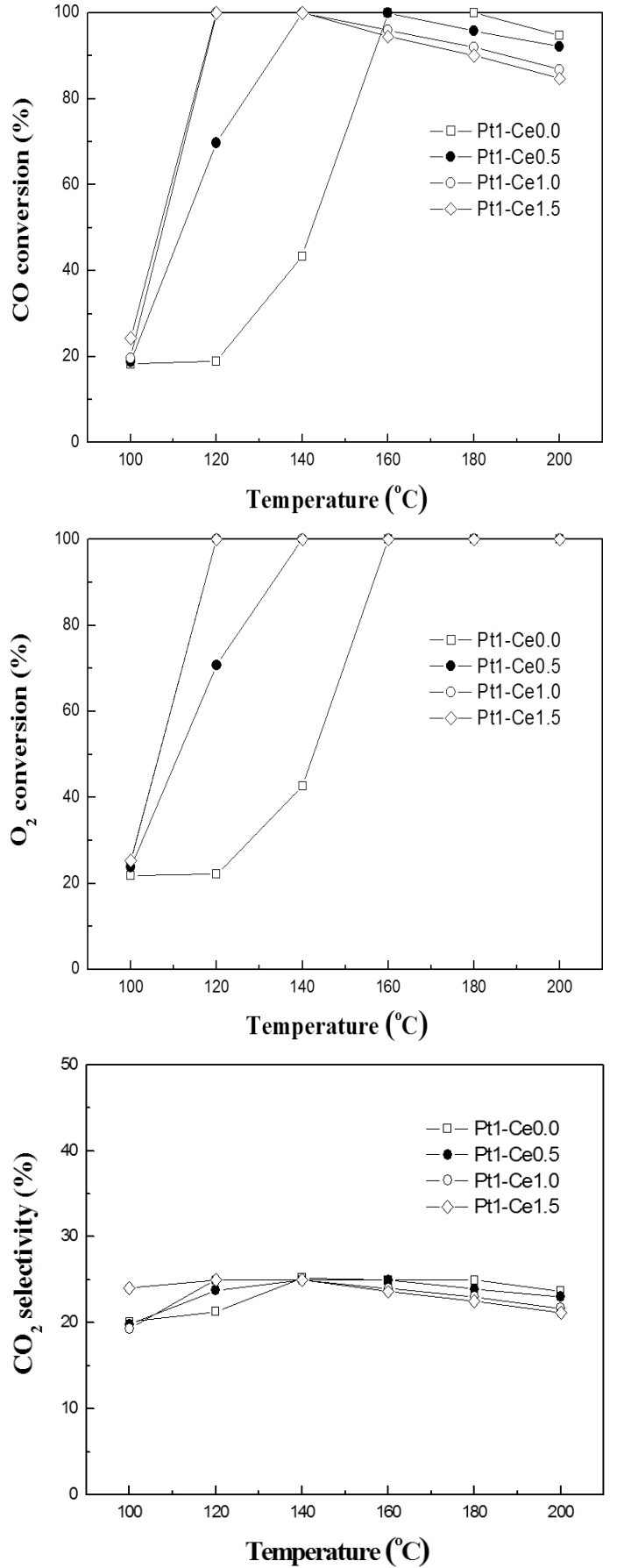

Fig. $2 \mathrm{CO}$ conversion, $\mathrm{O}_{2}$ conversion and $\mathrm{CO}_{2}$ selectivity with the reaction temperatures over $1 \mathrm{wt} \% \mathrm{Pt}-\mathrm{Ce} / \mathrm{\gamma}-\mathrm{Al}_{2} \mathrm{O}_{3}$ catalysts with various $\mathrm{Ce}$ contents (reaction condition: $0.61 \% \mathrm{CO}$, $1.22 \% \mathrm{O}_{2}, 59 \% \mathrm{H}_{2}, \mathrm{~N}_{2}$ as balance, $\mathrm{F} / \mathrm{W}=60,000 \mathrm{ml} / \mathrm{g}_{\text {cat }} \cdot \mathrm{h}$ )

반응 온도 영역에 따른 제조 촉매의 $\mathrm{CO}$ 전환율과 
Table 2 Reaction results over $1 \mathrm{wt} \% \mathrm{Pt}-\mathrm{Ce} / \mathrm{\gamma}-\mathrm{Al}_{2} \mathrm{O}_{3}$ catalysts with various $\mathrm{Ce}$ contents under different feed composition at $140^{\circ} \mathrm{C}$

\begin{tabular}{l|c|c|c|c|c|c}
\hline \hline \multirow{2}{*}{ Feed composition } & \multicolumn{2}{|c|}{$\mathrm{CO}$ conversion (\%) } & \multicolumn{2}{c|}{$\mathrm{O}_{2}$ conversion (\%) } & \multicolumn{2}{c}{$\mathrm{CO}_{2}$ selectivity (\%) } \\
\cline { 2 - 6 } & $\mathrm{Ce} 0.5 \%$ & $\mathrm{Ce} 1.0 \%$ & $\mathrm{Ce} 0.5 \%$ & $\mathrm{Ce} 1.0 \%$ & $\mathrm{Ce} 0.5 \%$ & $\mathrm{Ce} 1.0 \%$ \\
\hline $0.61 \% \mathrm{CO}, 1.22 \% \mathrm{O}_{2}, 59 \% \mathrm{H}_{2}$ in $\mathrm{N}_{2}$ & 100 & 100 & 100 & 100 & 25 & 25 \\
\hline $\begin{array}{l}0.61 \% \mathrm{CO}, 1.22 \% \mathrm{O}_{2}, 19 \% \mathrm{H}_{2} \mathrm{O}, 59 \% \\
\mathrm{H}_{2} \text { in } \mathrm{N}_{2}\end{array}$ & 100 & 100 & 100 & 100 & 25 & 25 \\
\hline $\begin{array}{l}0.61 \% \mathrm{CO}, 1.22 \% \mathrm{O}_{2}, 16 \% \mathrm{CO}_{2}, 59 \% \\
\mathrm{H}_{2} \text { in } \mathrm{N}_{2}\end{array}$ & 99.2 & 93.3 & 100 & 100 & 24.9 & 22.6 \\
\hline $\begin{array}{l}0.61 \% \mathrm{CO}, 1.22 \% \mathrm{O}_{2}, 19 \% \mathrm{H}_{2} \mathrm{O}, 16 \% \\
\mathrm{CO}_{2}, 59 \% \mathrm{H}_{2} \text { in } \mathrm{N}_{2}\end{array}$ & 100 & 95.2 & 100 & 100 & 25 & 23.8 \\
\hline
\end{tabular}

$\mathrm{CO}_{2}$ 선택도를 고려하여 $0.5 \mathrm{wt} \%$ 와 $1.0 \mathrm{wt} \% \mathrm{Ce}$ 를 첨 가한 촉매의 반응 변수에 대한 영향을 살펴봄으로써 실제 공정에 적용 가능한 선택적 $\mathrm{CO}$ 산화반응용 $\mathrm{Pt}-\mathrm{Ce} / \mathrm{\gamma}-\mathrm{Al}_{2} \mathrm{O}_{3}$ 촉매의 $\mathrm{Ce}$ 함량을 최적화하고자 하였다.

\section{3 불순물 $\left(\mathrm{H}_{2} \mathrm{O}, \mathrm{CO}_{2}\right)$ 영향}

실제 개질가스 내에 존재하는 불순물 $\left(\mathrm{H}_{2} \mathrm{O}, \mathrm{CO}_{2}\right)$ 은 선택적 $\mathrm{CO}$ 산화반응 촉매의 반응 활성을 감소시 키므로 이에 대한 저항성이 있는 촉매가 요구되어진 다. 앞서 $140^{\circ} \mathrm{C}$ 이하의 저온에서 향상된 $\mathrm{CO}$ 산화 활 성을 보인 $0.5 \mathrm{wt} \%$ 와 $1.0 \mathrm{wt} \% \mathrm{Ce}$ 를 첨가한 $\mathrm{Pt}-\mathrm{Ce} / \gamma$ $-\mathrm{Al}_{2} \mathrm{O}_{3}$ 촉매의 불순물에 대한 영향을 살펴보았으며 그 결과를 Table 2에 정리하였다.

반응 가스 내 $\mathrm{H}_{2} \mathrm{O}$ 이 존재하는 경우에 각각의 촉 매 모두 $100 \%$ 의 CO 전환율을 보이며 촉매활성 저하 가 관찰되지 않았다. 이러한 결과는 반응가스 내 $\mathrm{H}_{2} \mathrm{O}$ 의 해리 흡착으로 촉매 표면에 형성된 수산기가 $\mathrm{O}_{2}$ 보다 더 나은 산화제로 작용하여 산화 속도를 증 가시킴으로써 $\mathrm{CO}$ 전환율이 증가한 것으로 Manasilp 등은 설명하였다 ${ }^{2)}$.

반응 가스 내 $\mathrm{CO}_{2}$ 가 존재하는 경우, $\mathrm{Pt}-\mathrm{Ce} / \gamma-\mathrm{Al}_{2} \mathrm{O}_{3}$ 촉매 모두 $\mathrm{CO}$ 전환율과 $\mathrm{CO}_{2}$ 선택도가 감소하였다. 그러나, $0.5 \mathrm{wt} \% \mathrm{Ce}$ 가 첨가된 촉매의 $\mathrm{CO}$ 전환율과 $\mathrm{CO}_{2}$ 선택도는 $99.2 \%$ 와 $24.9 \%$ 로 $1 \mathrm{wt} \% \mathrm{Ce}$ 가 첨가된 촉매의 $\mathrm{CO}$ 전환율(93.3\%)과 $\mathrm{CO}_{2}$ 선택도(22.6\%)보다 높았다. $\mathrm{CO}_{2}$ 첨가로 인한 촉매활성 감소의 이유는 활성산소를 제공하는 $\mathrm{Pt}$ 결정과 알루미나의 계면 사
이에 $\mathrm{CO}_{2}$ 가 흡착되어 산소이동을 제한하기 때문이 다). 마찬가지로, $\mathrm{Ce}$ 첨가량이 증가함에 따라 $\mathrm{CO}_{2}$ 불순물에 의한 촉매 산화활성 및 선택도 감소가 뚜 렷하게 나타남을 확인하였다.

$\mathrm{H}_{2} \mathrm{O}$ 와 $\mathrm{CO}_{2}$ 가 동시에 존재하는 경우, $0.5 \mathrm{wt} \% \mathrm{Ce}$ 를 첨가한 촉매는 $\mathrm{CO}_{2}$ 만 존재하는 경우보다 오히려 $\mathrm{CO}$ 산화 활성이 향상되어 $100 \% \mathrm{CO}$ 전환율을 보였 다. 반면에 $1.0 \mathrm{wt} \% \mathrm{Ce}$ 를 첨가한 촉매는 $\mathrm{CO}_{2}$ 에 의한 산화활성 감소 영향이 커 $\mathrm{CO}$ 전환율은 $95.2 \%, \mathrm{CO}_{2}$ 선택도는 $23.8 \%$ 를 보였다. 그러나 두 촉매 모두 $\mathrm{CO}_{2}$ 만 단독으로 존재할 경우보다 약간 $\mathrm{CO}$ 전환율과 $\mathrm{CO}_{2}$ 선택도가 증가하였는데 이는 $\mathrm{H}_{2} \mathrm{O}$ 에 의한 산화활성 상승효과가 $\mathrm{CO}_{2}$ 에 의한 산화활성 감소효과보다 큰

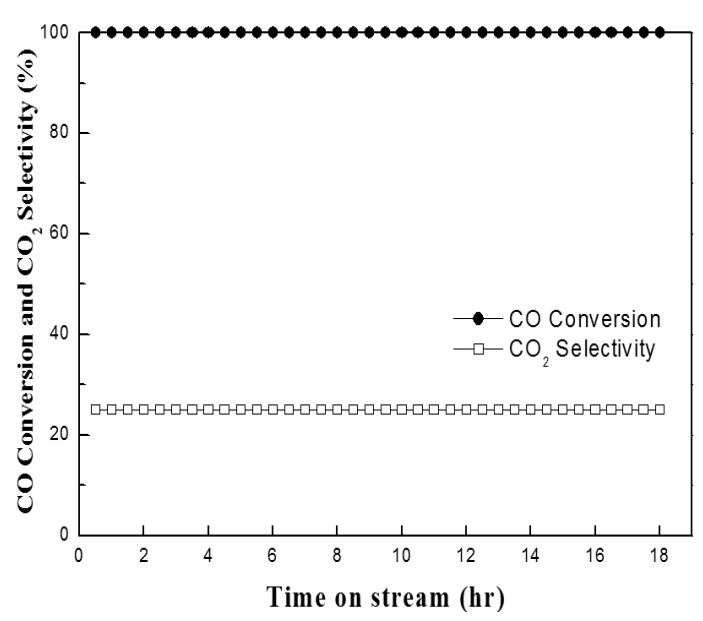

Fig. $3 \mathrm{CO}$ conversion and $\mathrm{CO}_{2}$ selectivity with time on stream(TOS) over $1 \mathrm{wt} \% \mathrm{Pt}-\mathrm{Ce} / \mathrm{\gamma}-\mathrm{Al}_{2} \mathrm{O}_{3}$ catalyst with $0.5 \% \mathrm{Ce}$ (reaction condition: $0.61 \% \mathrm{CO}, 1.22 \% \mathrm{O}_{2}, 59 \% \mathrm{H}_{2}, 19 \% \mathrm{H}_{2} \mathrm{O}$, $16 \% \mathrm{CO}_{2}, \mathrm{~N}_{2}$ as balance, $\mathrm{T}=140^{\circ} \mathrm{C}, \mathrm{F} / \mathrm{W}=60,000 \mathrm{ml} / \mathrm{g}_{\text {cat }} \cdot \mathrm{h}$ ) 
것으로 볼 수 있달.

불순물 $\left(\mathrm{H}_{2} \mathrm{O}, \mathrm{CO}_{2}\right)$ 영향을 살펴본 결과, $140^{\circ} \mathrm{C}$ 의 저온 영역에서 $\mathrm{Ce}$ 를 첨가한 $\mathrm{Pt}-\mathrm{Ce} / \mathrm{\gamma}-\mathrm{Al}_{2} \mathrm{O}_{3}$ 촉매의 불 순물 $\left(\mathrm{H}_{2} \mathrm{O}, \mathrm{CO}_{2}\right)$ 에 의한 촉매활성 감소 영향은 크지 않은 것으로 확인되었다. 그 중에서 $0.5 \% \mathrm{Ce}$ 를 첨가 한 $\mathrm{Pt} / \mathrm{\gamma}-\mathrm{Al}_{2} \mathrm{O}_{3}$ 촉매는 불순물 $\left(\mathrm{H}_{2} \mathrm{O}, \mathrm{CO}_{2}\right)$ 에 대한 높은 저항성으로 우수한 $\mathrm{CO}$ 산화 활성과 $\mathrm{CO}_{2}$ 선택성을 보였다.

Fig. 3은 $0.5 \% \mathrm{Ce}$ 를 첨가한 $\mathrm{Pt}-\mathrm{Ce} / \gamma-\mathrm{Al}_{2} \mathrm{O}_{3}$ 촉매의 반응 안정성을 살펴보기 위해 불순물 $\left(\mathrm{H}_{2} \mathrm{O}, \mathrm{CO}_{2}\right)$ 이 존재하는 조건에서 $140^{\circ} \mathrm{C}$ 에서 18 시간동안 선택적 $\mathrm{CO}$ 산화 반응을 수행한 결과이다. $\mathrm{CO}$ 전환율과 $\mathrm{CO}_{2}$ 선택도는 각각 $100 \%$ 와 $25 \%$ 로 반응 시간동안 안정 한 반응 활성을 보였으며, $\mathrm{O}_{2}$ 전환율 역시 $100 \%$ 를 유지하며 $\mathrm{CO}$ 전환율과 같은 경향을 보였다. 결과적 으로, $0.5 \% \mathrm{Ce}$ 를 첨가한 $1 \mathrm{wt} \% \mathrm{Pt}-0.5 \mathrm{wt} \% \mathrm{Ce} / \mathrm{\gamma}-\mathrm{Al}_{2} \mathrm{O}_{3}$ 촉매가 $\mathrm{H}_{2} \mathrm{O}$ 와 $\mathrm{CO}_{2}$ 불순물이 동시에 존재하는 경우 에서도 우수한 $\mathrm{CO}$ 산화활성과 안정성을 보이는 것 을 확인하였다.

\section{4. 결 론}

본 연구에서는 $150^{\circ} \mathrm{C}$ 이하의 저온에서 $\mathrm{Pt}$ 촉매의 $\mathrm{CO}$ 산화반응 활성을 향상시키기 위해 $\mathrm{Ce}$ 를 조촉매 로 첨가하여 $1 \mathrm{wt} \% \mathrm{Pt}-\mathrm{Ce} / \gamma-\mathrm{Al}_{2} \mathrm{O}_{3}$ 촉매를 제조하였 다. $\mathrm{Ce}$ 함량이 증가할수록 $\mathrm{Pt}$ 분산도는 약간 감소하 였으나 $\mathrm{Ce}$ 의 산화환원특성으로 인한 저온에서 촉매 의 환원성이 증가하여 $150^{\circ} \mathrm{C}$ 이하에서 촉매의 $\mathrm{CO}$ 산 화 활성이 크게 향상되었다. 그러나, $\mathrm{Ce}$ 함량을 $1 \mathrm{wt} \%$ 이상으로 첨가할 경우, 경쟁반응인 $\mathrm{H}_{2}$ 산화반응이 함께 촉진되어 $160^{\circ} \mathrm{C}$ 이상에서는 $\mathrm{CO}$ 전환율과 $\mathrm{CO}_{2}$ 선택도가 감소하였다. $\mathrm{Pt}-\mathrm{Ce} / \gamma-\mathrm{Al}_{2} \mathrm{O}_{3}$ 촉매의 실제 개 질가스 내에 존재하는 불순물 $\left(\mathrm{H}_{2} \mathrm{O}, \mathrm{CO}_{2}\right)$ 에 대한 영 향을 살펴본 결과, $0.5 \mathrm{wt} \% \mathrm{Ce}$ 를 첨가한 $\mathrm{Pt} / \mathrm{\gamma}-\mathrm{Al}_{2} \mathrm{O}_{3}$ 촉매가 불순물 피독에 대한 저항성이 가장 우수하였 으며, $140^{\circ} \mathrm{C}$ 의 저온 반응에서 불순물 $\left(\mathrm{H}_{2} \mathrm{O}, \mathrm{CO}_{2}\right)$ 존 재 하에서도 $100 \%$ 의 CO 전환율을 유지하며 안정한 $\mathrm{CO}$ 산화 활성을 보였다. 결과적으로, $\mathrm{Ce}$ 첨가를 통
한 $\mathrm{Pt}$ 촉매의 저온 환원성 향상으로 $150^{\circ} \mathrm{C}$ 이하의 저 온에서 $\mathrm{CO}$ 산화 반응활성과 $\mathrm{CO}_{2}$ 선택성을 향상시킬 수 있었다.

\section{후 기}

본 연구는 지식경제부 신재생융합원천기술개발사 업(20123010040010) 및 한국에너지기술연구원 주요 사업의 일환으로 수행되었습니다.

\section{참 고 문 헌}

1. J. L. Ayastuy, M. P. Gonzalez-Marcos, M. A. Gutierrez-Oriz, "Promotion Effect of $\mathrm{Sn}$ in Alumina-supported Pt Catalysts for CO-PROX", Catalysis Communications, Vol. 12, 2011, pp. 895-900.

2. A. Manasilp, E. Gulari, "Selective CO Oxidation over Pt/alumina Catalysts for Fuel Cell Applications", Applied Catalysis B:environmental, Vol. 37, 2002, pp. 17-25.

3. M. Echigo, T. Tabata, "A Study of CO Removal on an Activated Ru Catalyst for Polymer Electrolyte Fuel Cell Applications", Applied Catalysis A:General, Vol. 251, 2003, pp. 157-166.

4. J. L. Ayastuy, M. P. Gonzalez-Marcos, M. A. Gutierrez-Oriz, "Effect of Process Variables on $\mathrm{Pt} / \mathrm{CeO}_{2}$ Catalyst Behaviour for the PROX Reaction", International Journal of Hydrogen Energy, Vol. 31, 2006, pp. 2231-2242.

5. J. W. Park, J. H. Jeong, W. L. Yoon, C. S. Kim, D. K. Lee, "Selective Oxidation of $\mathrm{CO}$ in Hydrogen-rich stream over $\mathrm{Cu}-\mathrm{Ce}$ Catalyst promoted with Transition Metals", International Journal of Hydrogen Energy, Vol. 30, 2005, pp. 209-220.

6. H. J. Eom, K. Y. Koo, U. H. Jung, Y. W. Rhee, W. L. Yoon, "Preparation of Highly Dispersed $\mathrm{Ru} / \mathrm{a}-\mathrm{Al}_{2} \mathrm{O}_{3}$ Catalyst for Preferential CO Oxidation", Trans. of the Korean Hydrogen and New Energy Society, Vol. 21, 2010, pp. 390-397. 
7. C. Y. Huang, Y. Y. Chen, C. C. Su, C. F. Hsu, "The Cleanup of $\mathrm{CO}$ in Hydrogen for PEMFC Applications using $\mathrm{Pt}, \mathrm{Ru}, \mathrm{Co}$, and $\mathrm{Fe}$ in PROX Reaction", Journal of Power Sources, Vol. 174, 2007, pp. 294-301.

8. M. M. Schubert, S. Hackenberg, A. V. V. Veen, M. Muhler, V. Plzak, R. J. Behm, "CO Oxidation over Supported Gold Catalysts - "Inert" and "Active" Support Materials and Their Role for the Oxygen Supply during Reaction", Journal of Catalysis, Vol. 197, 2001, pp. 113-122.

9. I. H. Son, "Study of Ce-Pt/ $/-\mathrm{Al}_{2} \mathrm{O}_{3}$ for the Selective Oxidation of $\mathrm{CO}$ in $\mathrm{H}_{2}$ for Application to PEFSs: Effect of Gases", Journal of Power Sources, Vol. 159, 2006, pp. 1266-1273.

10. Y. Minemura, S. Ito, T. Miyao, S. Naito, K. Tomishige, K. Kunimori, "Preferential CO Oxidation Promoted by the Presence of $\mathrm{H}_{2}$ over $\mathrm{K}^{-}$ $\mathrm{Pt} / \mathrm{Al}_{2} \mathrm{O}_{3}$ ", Chemical Communications, 2005, pp. 1429-1431.

11. X. Liu, O. Korotkikh, R. Farrauto, "Selective Catalytic Oxidation of $\mathrm{CO}$ in $\mathrm{H}_{2}$ : Structural Study of Fe oxide-promoted Pt/alumina Catalyst", Applied Catalysis A: General, Vol. 226, 2002, pp. 293-303.

12. E. Y. Ko, E. D. Park, K. W. Seo, H. C. Lee, D. H. Lee, S. H. Kim, "Pt-Ni/ $/-\mathrm{Al}_{2} \mathrm{O}_{3}$ Catalyst for the Preferential CO Oxidation in the Hydrogen Stream”, Catalysis Letters, Vol. 110, 2006, pp. 275-279.

13. J. Yan, J. Ma, P. Cao, P. Li, "Preferential Oxidation of $\mathrm{CO}$ in $\mathrm{H}_{2}$-Rich Gases over Co-Promoted $\mathrm{Pt} / \mathrm{\gamma}-\mathrm{Al}_{2} \mathrm{O}_{3}$ Catalyst”, Catalysis Letters, Vol. 93, 2004, pp. 55-60.

14. S. Y. Shin, O. S. Alexeev, M. D. Amiridis, "Structure and Reactivity of Pt-Ru/ $\mathrm{SiO}_{2}$ Catalysts for the Preferential Oxidation of $\mathrm{CO}$ under Excess $\mathrm{H}_{2}$ ", Journal of Catalysis, Vol. 243, 2006, pp. 329-339.

15. H. S. Roh, D. W. Jeong, K. S. Kim, I. H. Eum, K. Y. Koo, W. L. Yoon, "Single Stage WaterGas Shift Reaction over Supported Pt Catalysts", Catalysis Letters, Vol. 141, 2011, pp. 95-99.

16. D. W. Jeong, J. O. Shim, W. J. Jang, H. S. Roh, "A Study of $\mathrm{Pt} / \mathrm{Na} / \mathrm{CeO}_{2}$ Catalysts for Single Stage Water Gas Shift Reaction", Trans. of the Korean Hydrogen and New Energy Society, Vol. 23, 2012, pp.111-116.

17. H. Liu, L. Ma, S. Shao, Z. Li, A. Wang, "Preferential $\mathrm{CO}$ Oxidation on Ce-promoted $\mathrm{Pt} / \gamma$ $-\mathrm{Al}_{2} \mathrm{O}_{3}$ Catalysts under $\mathrm{H}_{2}$-rich Atmosphere", Chin J. Catal., Vol. 28, 2007, pp. 1077-1082. 